GO INFOTECH: JURNAL ILMIAH STMIK AUB

Vol.25, No.2, Desember 2019

ISSN (p): 1693-590x, ISSN (e): 2686-4711

DOI: $10.36309 /$ goi.v25i2.108

\title{
Aplikasi Perpustakaan STMIK AUB Surakarta Berbasis Android
}

\author{
Ratna Herawati ${ }^{1}$, Hartati Dyah Wahyuningsih ${ }^{2}$, Ayub Kukuh Prasetyo ${ }^{3}$ \\ ${ }^{123}$ Program Studi Sistem Informasi, STMIK AUB, Surakarta, Indonesia \\ e-mail: *1 ratna.herawati@stmik-aub.ac.id, ${ }^{2}$ hartati.dyah@stmik-aub.ac.id, ${ }^{3}$ ayubk@gmail.com
}

\begin{abstract}
Abstrak
Perpustakaan STMIK AUB Surakarta saat ini menggunakan sistem informasi perpustakaan. Dengan adanya sistem yang masih belum efisien untuk mengatasi pencarian dan peminjaman buku oleh anggota. Anggota masih harus melakukan pencarian buku dan transaksi peminjaman buku diperpustakaan yang belum dilakukan secara online. Tujuan penelitian ini adalah membangun Aplikasi Perpustakaan STMIK AUB Surakarta Berbasis Android. Dalam membangun sistem tersebut metode pendekatan yang digunakan adalah metode perancangan dengan menggunakan metode waterfall. Metode pengumpulan data dengan metode wawancara, metode observasi dan metode pustaka. Sebagai alat bantu analisis dan perancangan yang digunakan adalah flowchart UML (Unified Moddeling Languange). Sedangkan bahasa pemograman pendukung yang digunakan adalah Android Studio versi 3.0.1, PHP, Java, dan My SQL sebagai database. Dengan adanya aplikasi perpustakaan STMIK AUB Surakarta berbasis android, diharapkan dapat meningkatkan kinerja layanan informasi, transaksi peminjaman di Perpustakaan STMIK AUB Surakarta dan lebih efisien.
\end{abstract}

Kata kunci: Aplikasi, Perpustakaan, Android, PHP

\section{PENDAHULUAN}

Perpustakaan STMIK AUB Surakarta saat ini menggunakan sistem informasi perpustakaan. Dengan adanya sistem yang masih belum efisien untuk mengatasi pencarian dan peminjaman buku oleh anggota. Anggota masih harus melakukan pencarian buku dan transaksi peminjaman buku diperpustakaan yang belum dilakukan secara online. Anggota perpustakaan dapat lebih mudah dalam mencari informasi buku dan melakukan peminjaman buku yang dibutuhkan. Pendaftaran anggota melalui aplikasi android. Aturan pemesanan buku yang telah di pesan harus diambil pada hari pemesanan dan diberikan batas waktu selama 30 menit setelah pemesanan buku. Jika buku yang telah dipesan tidak diambil pada saat hari pemesanan dan melebihi batas waktu yang sudah ditentukan maka buku tersebut akan dibatalkan otomatis oleh sistem. Anggota harus melakukan pemesanan ulang jika buku yang ingin di pinjam telah dibatalkan. Peminjaman buku adapun batas jumlah peminjaman koleksi buku dan waktu peminjaman dari masing-masing jenis keanggotan yang ada adalah mahasiswa maksimal 2 eksemplar dengan tenggang waktu 2 minggu dan satu kali perpanjang. dosen dan karyawan maksimal 3 eksemplar dengan tenggang waktu 3 minggu dan satu kali perpanjang. Keterlambatan pengembalian buku akan dikenakan denda Rp.500,-/buku/hari. Perpanjangan buku atas buku yang dipinjam dapat dilakukan oleh peminjam apabila memenuhi dengan syarat belum pernah diperpanjang.

Pada perancangan sistem perpustakaan STMIK AUB Surakarta berbasis android menggunakan metode pengumpulan data yaitu metode wawancara, observasi dan studi pustaka. Yang menggunakan sumber data primer dan data sekunder. Untuk metode perancangan sistem menggunakan Flowchart, UML (Unified Modeling Language) yang tediri dari Usecase Diagram, Activity Diagram, Sequence Diagram, Class Diagram, dan Entity Relationship

Received November 11, 2019; Revised November 25, 2019; Accepted December 9, 2019 
Diagram. Sedangkan untuk metode pengembangan sistem menggunakan metode Waterfall. Hasil dari perancangan sistem yaitu Sistem Pepustakaan STMIK AUB berbasis android. Pengembangan sistem menggunakan bahasa pemrograman Java, tool yang digunakan yaitu Android Studio Versi 3.0.1, pada website menggunakan bahasa pemrograman PHP, dan SQL sebagai database. Pada sisi server, sistem ini dapat melakukan pengolahan data buku, aktivasi data anggota, sirkulasi peminjaman pengembalian buku dan pembuatan laporan. Pada sisi client sistem dapat melakukan peminjaman buku, perpanjangan masa pinjman buku dan melihat riwayat peminjaman buku.

Adanya Aplikasi Perpustakaan STMIK AUB Surakarta Berbasis Android, memberikan media baru bagi anggota dalam menyediakan layanan informasi koleksi buku dan peminjaman buku secara online. Selain itu juga dilengkapi dengan daftar peminjaman koleksi buku, riwayat peminjaman koleksi buku, usulan penambahan koleksi buku, berita terbaru seputar perpustakaan dan adanya notification saat buku telah dikembalikan. Hasil dari penelitian ini adalah Aplikasi Perpustakaan STMIK AUB Surakarta Berbasis Android, dengan adanya aplikasi ini diharapkan dapat meningkatkan kinerja layanan informasi, transaksi peminjaman di Perpustakaan STMIK AUB.

\section{METODE PENELITIAN}

\subsection{Analisis PIECES}

Untuk menganalisa kelemahan sistem diperlukan langkah untuk mengidentifikasi dan memberikan solusi terhadap kelemahan sistem yang ada, maka sebagai landasan penulis menggunakan metode atau kerangka PIECES (Performance, Information, Economy, Control, Efficiency dan Service). Tujuan dari analisa PIECES adalah untuk mengoreksi atau memperbaiki sistem lama.

Dari hal-hal yang telah didefinisikan tersebut dapat diambil beberapa masalah yang sesuai dengan yang dihadapi oleh organisasi, kemudian dideskripsikan. Sehingga masalah tersebut dapat dipahami dengan baik. Berikut ini daftar identifikasi masalah, kesempatan dan perintah. (Jeffrey, 2001)

\section{a. Performance}

1. Produksi, jumlah kerja selama periode waktu tertentu. Pada bagian ini dideskripsikan situasi saat ini tentang jumlah kerja yang dibutuhkan untuk melakukan serangkaian kerja tertentu dalam satuan orang jam, orang hari, atau orang bulan. Misalnya: untuk memproses 1 berkas yang masuk kepada organisasi dibutuhkan berapa orang jam? kemudian hal ini dianalisis apakah hasil kerja yang demikian ini sudah bagus atau perlu ada peningkatan kinerja.

2. Waktu respons, penundaan rata-rata antara transaksi atau permintaan dengan respons ke transaksi atau permintaan tersebut. Pada bagian ini dideskripsikan situasi saat ini tentang waktu respons yang terjadi ketika ada suatu transaksi yang masuk hingga transaksi tersebut direspons untuk diproses. Penundaan ini bisa jadi karena antrian dalam pemrosesan transaksi-transaksi sebelumnya.

b. Information

1. Kurangnya informasi, kurangnya informasi yang diperlukan, kurangnya informasi yang relevan. Tiga hal yang telah disebutkan itu bersumber pada kurangnya informasi bagaimanapun bentuknya. Pada bagian ini dideskripsikan situasi saat ini tentang kurangnya informasi yang dibutuhkan untuk pengambilan keputusan.

2. Terlalu banyak informasi (kelebihan informasi), yang dimaksud terlalu banyak informasi di sini adalah banyaknya informasi yang berserakan, belum terkumpul, belum terformat, dan masih tercampurnya antara informasi yang relevan dan yang tidak relevan dengan masalah yang harus diambil keputusannya, sehingga memerlukan waktu yang lebih lama untuk memilah dan memilih informasi yang relevan, selain itu juga informasi yang sama disampaikan berulang-ulang. Pada bagian ini dideskripsikan situasi saat ini tentang terlalu

GO INFOTECH: JURNAL ILMIAH STMIK AUB Vol. 25, No. 2, Desember 2019: 97-111 
banyaknya informasi yang demikian itu, pada bagian mana terjadi produksi informasi yang berlebihan, dan penyebab terjadinya produksi informasi yang berlebihan tersebut.

3. Informasi tidak dalam format yang berguna, yang dimaksud informasi tidak dalam format yang berguna adalah bahwa informai tersebut sudah tersedia, hanya saja bentuk dan formatnya tidak sesuai dengan yang dibutuhkan sehingga mempersulit pembacaan informasi tersebut dan memerlukan waktu yang lebih lama untuk memahami dan memanfaatkan informasi tersebut. Pada bagian ini dideskripsikan situasi saat ini tentang informasi-informasi yang tersedia tidak dalam format yang dibutuhkan untuk pengambilan keputusan.

4. Informasi tidak akurat, yang dimaksud informasi tidak akurat adalah bahwa informasi tersebut tidak sesuai dengan keadaan yang sebenarnya. Tidak akuratnya informasi tersebut dapat disebabkan oleh berbagai hal. Pada bagian ini dideskripsikan situasi saat ini tentang informasi yang tidak akurat tersebut, deskripsi tentang ketidak akuratannya beserta dengan penyebab-penyebab ketidak akuratannya.

5. Informasi sulit diproduksi, yang dimaksud informasi yang sulit diproduksi adalah bahwa informasi tersebut tidak mudah dalam proses produksinya, ini terjadi karena berbagai sebab, diantaranya data yang tidak lengkap baik dalam jumlah maupun macamnya, sumber informasi yang sulit didapatkan informasinya, format informasi yang terlalu sulit dipahami dan diproduksi informasinya, pemrosesan data melalui prosedur yang rumit, dan masih banyak lagi penyebab yang lainnya. Pada bagian ini dideskripsikan situasi saat ini tentang informasi yang sulit diproduksi, letak kesulitan produksinya, dan penyebab kesulitan produksinya.

6. Informasi yang tidak tepat waktunya untuk penggunaan selanjutnya, yang dimaksud informasi yang tidak tepat waktunya untuk penggunaan selanjutnya adalah bahwa informasi tersebut datang tidak pada waktu yang tepat, baik dalam hal waktu datangnya ataupun situasi yang terjadi ketika informasi tersebut datang.

c. Economy

1. Biaya tidak diketahui, pada bagian ini dideskripsikan situasi saat ini tentang biaya yang dikeluarkan untuk memproduksi informasi, melakukan proses bisnis, dan mengambil keputusan tidak diketahui jumlahnya dan pos pembiayaannya. Selain itu juga dideskripsikan penyebab biaya tidak diketahui, dan dampak yang ditimbulkan ketika hal tersebut terjadi.

2. Biaya tidak dapat dilacak ke sumber, pada bagian ini dideskripsikan situasi saat ini tentang biaya yang dikeluarkan untuk memproduksi informasi, melakukan proses bisnis, dan mengambil keputusan tidak dapat dilacak ke sumbernya sehingga tidak dapat diketahui keakuratan biayanya. Selain itu juga dideskripsikan penyebab biaya tidak dilacak ke sumbernya, dan dampak yang ditimbulkan ketika hal tersebut terjadi.

3. Biaya terlalu tinggi, pada bagian ini dideskripsikan situasi saat ini tentang biaya yang dikeluarkan untuk memproduksi informasi, melakukan proses bisnis, dan mengambil keputusan terlalu tinggi dan banyaknya pos pembiayaan. Selain itu juga dideskripsikan penyebab biaya terlalu tinggi, dan dampak yang ditimbulkan ketika hal tersebut terjadi.

\section{d. Control}

Pada bagian ini dideskripsikan situasi saat ini tentang kendali terhadap aliran data dan informasi ketika keamanan atau kendali terlalu lemah sehingga data dan informasi rentan terhadap pemanfaatan oleh pihak-pihak yang tidak berwenang terhadap pemanfaatan data dan informasi tersebut.

\section{e. Efficiency}

Sebagaimana telah dijelaskan sebelumnya pada bab informasi, di mana data yang secara berlebihan di-inputkan dan diproses juga informasi yang dihasilkan secara berlebihan akan membuat sistem tidak efisien dalam penggunaan sumberdaya. Sumberdaya dapat berupa sumberdaya prosesor, memory, ruang penyimpanan, listrik, personil.

f. Service 
Bagian ini dideskripsikan situasi saat ini tentang layanan yang disediakan oleh sistem yang berjalan saat ini. Sederetan kelemahan layanan sistem telah teridentifikasi di bawah ini, kemudian dideskripsikan juga penyebab kelemahan sistem tersebut, dan dampak yang ditimbulkan ketika hal tersebut terjadi.

2.2 Metode Penelitian

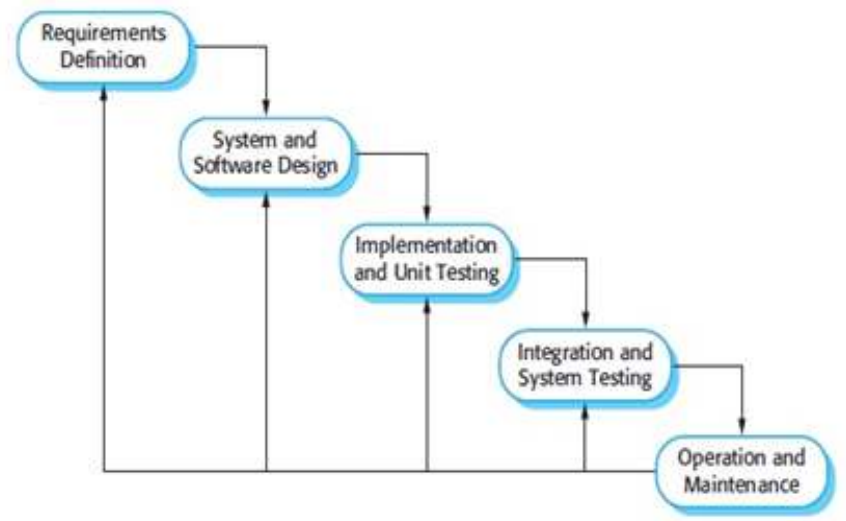

Gambar 1 Siklus Pengembangan Sistem dengan Metode Waterfall (Sommerville, 2011)

Siklus Pengembangan Sistem dengan Metode Waterfall (Sommerville, 2011) adalah tahapan umum dari model proses ini. Berikut adalah penjelasan dari tahap-tahap yang dilakukan di dalam model ini:

a. Requirements definition. Langkah ini merupakan analisa terhadap kebutuhan sistem. Pengumpulan data dalam tahap ini bisa melakukan sebuah penelitian, wawancara atau studi literatur.

b. System And Software Design. Proses desain akan menterjemahkan syarat kebutuhan kesebuah perancangan perangkat lunak yang dapat diperkirakan sebelum dibuat coding.

c. Implementation And Unit Testing. Merupakan penerjemah desain dalam Bahasa yang bisa dikenali oleh komputer.

d. Integration And Sytem Testing. Melakukan testing terhadap sistem yang telah dibuat. Tujuan testing adalah menemukan kesalahan-kesalahan terhadap sistem tersebut dan kemudian bisa diperbaiki.

e. Operation And Maintenance. Tahapan ini bisa dikatakan final dalam pembuatan sebuah sistem. Setelah melakukan analisa, desain dan pengkodean maka sistem yang sudah jadi akan digunakan oleh user.

2.3 Relasi Antar Tabel

GO INFOTECH: JURNAL ILMIAH STMIK AUB Vol. 25, No. 2, Desember 2019: 97-111 


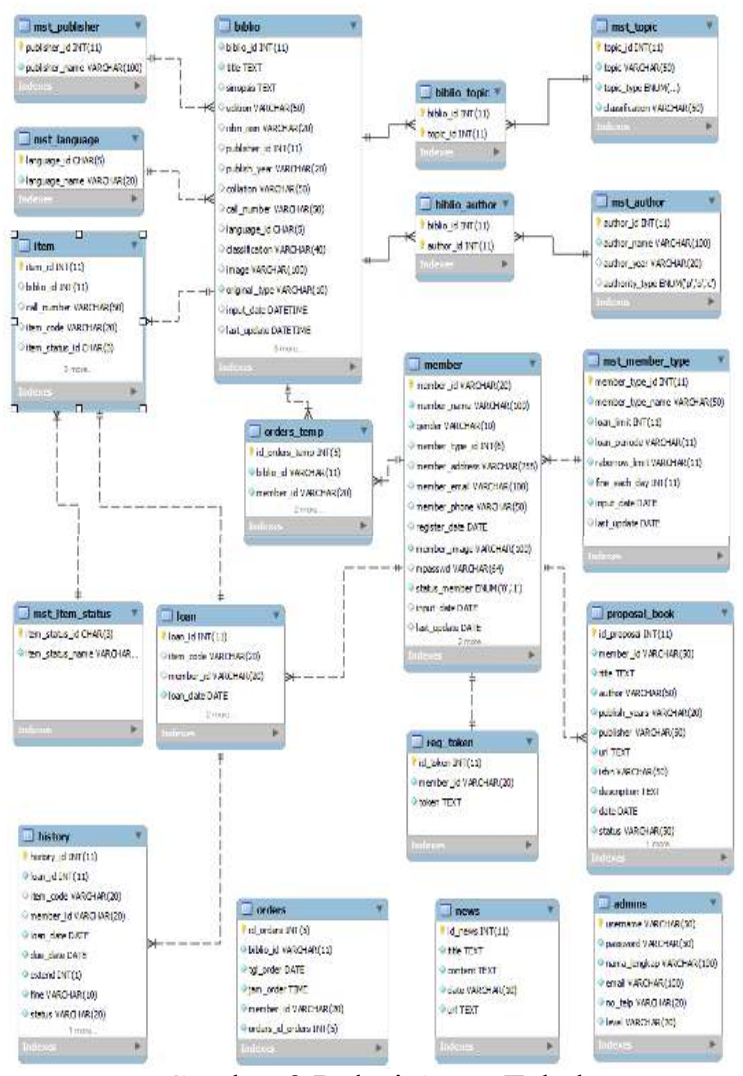

Gambar 2 Relasi Antar Tabel

Pada gambar 2 tabel mst publisher berhubungan dengan tabel biblio untuk membuat data penerbit dari setiap koleksi. Tabel biblio berhubungan dengan tabel biblio_topic dan mst_topic untuk membuat data topik dari setiap koleksi. Tabel biblio berhubungan dengan tabel biblio_author dan tabel mst_author untuk membuat data pengarang buku dari setiap koleksi. Tabel member berhubungan dengan tabel mst_member_type untuk membuat data tipe dari setiap anggota. Tabel item berhubungan dengan tabel biblio dan tabel mst_item_status untuk membuat data eksemplar dan status dari setiap koleksi. Tabel order tmp berhubungan dengan tabel bibilio dan tabel member yang digunakan untuk membuat data keranjang buku yang nantinya akan dipesan. Tabel loan berhubungan dengan tabel item dan tabel member yang digunakan untuk sirkulasi data peminjaman. Tabel loan berhubungan dengan tabel history untuk membuat daftar riwayat koleksi peminjaman yang telah dikembalikan. Tabel proposal_book berhubungan dengan tabel member untuk usulan koleksi oleh anggota. Tabel reg_token berhubungan dengan tabel member untuk membuat data token yang nantinya anggota dapat menerima notifikasi. Tabel orders untuk melihat data pemesanan koleksi yang dilakukan oleh anggota. Tabel news untuk membuat data berita perpustakaan. Tabel admins digunakan untuk pustakawan masuk kedalam sistem dan mengolah data perpustakaan.

\section{HASIL DAN PEMBAHASAN}

Dalam pembuatan aplikasi ini dibutuhkan suatu implementasi untuk menguraikan program dan analisis dari hasil program yang telah dibuat. Tujuan pembahasan ini adalah untuk mengetahui apakah program yang dibuat sudah bekerja seperti yang diharapkan atau belum. Berikut adalah proses pembahasan interface atau antarmuka program:

3.1 Antar muka halaman admin berbasis web

1. Halaman Login Admin

Aplikasi Perpustakaan STMIK AUB Surakarta Berbasis Android (Ratna) 
2. Halaman Beranda Admin

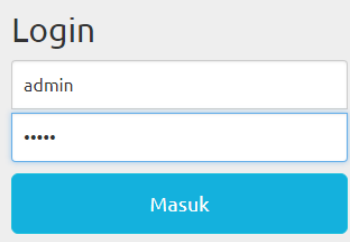

Gambar 3 Halaman Login Admin

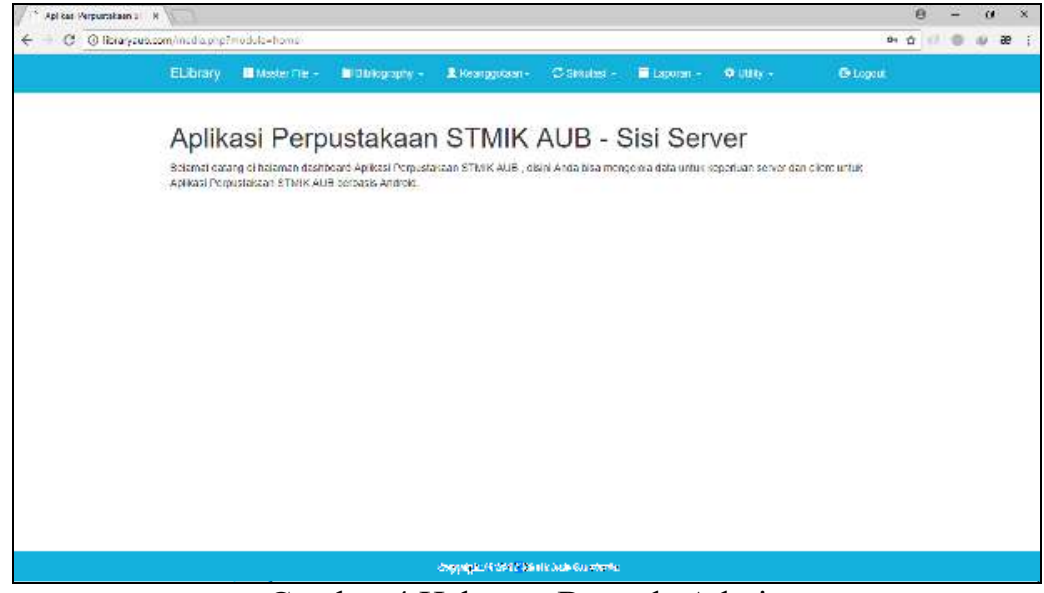

Gambar 4 Halaman Beranda Admin

3. Halaman Master Data Penerbit

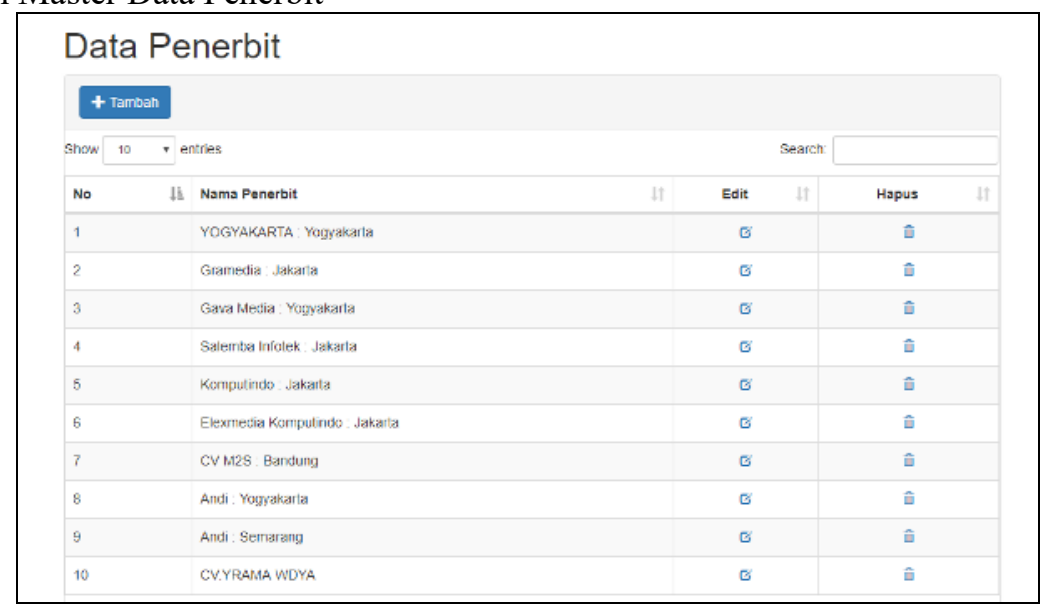

Gambar 5 Halaman Master Data Penerbit

4. Halaman Master Data Pengarang 


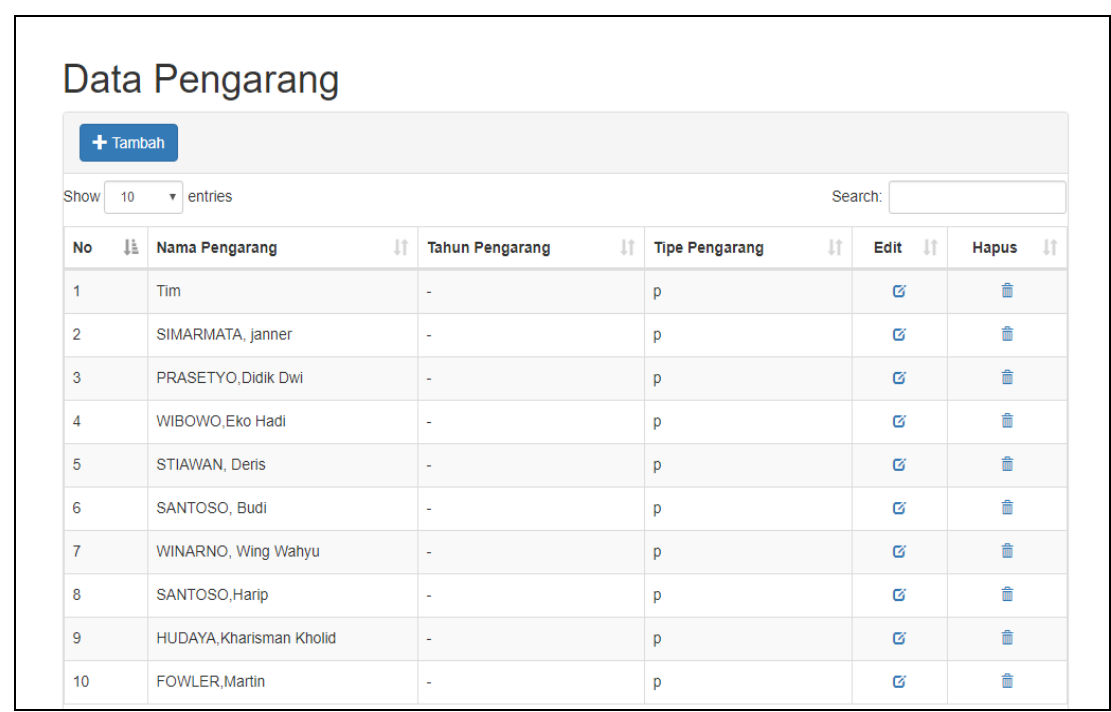

Gambar 5 Halaman Master Data Pengarang

5. Halaman Master Data Topik

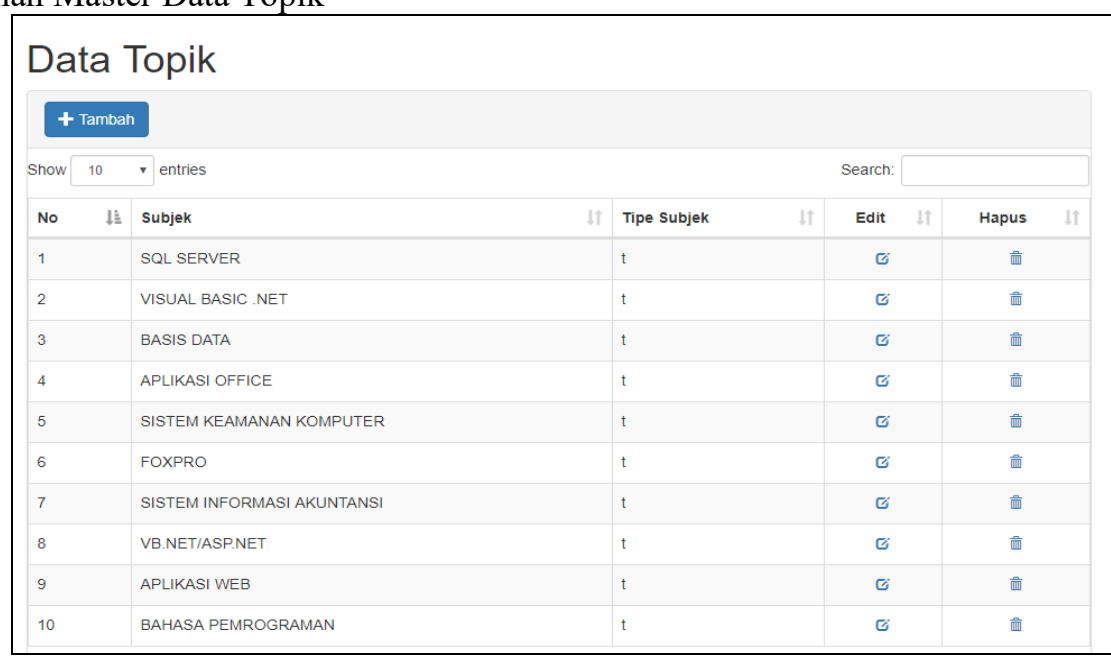

Gambar 6 Halaman Data Topik

6. Halaman Master Data Bahasa

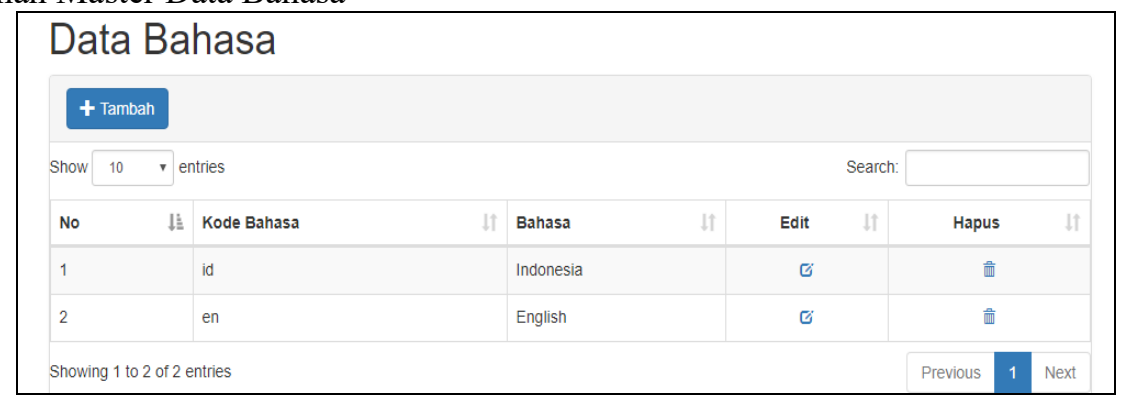

Gambar 7 Halaman Data Bahasa

7. Halaman Data Berita 


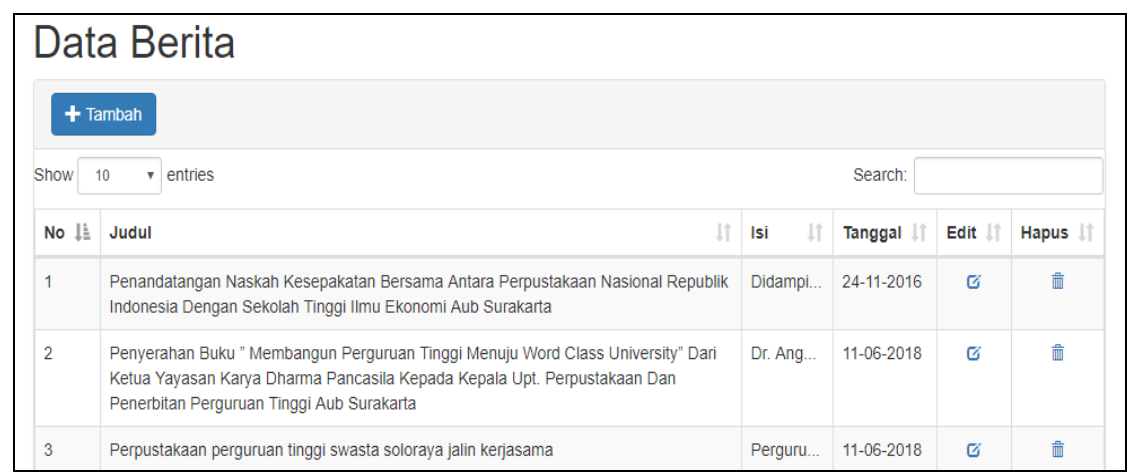

8. Halaman Data Bibliograpy

\section{Gambar 7 Halaman Data Berita}

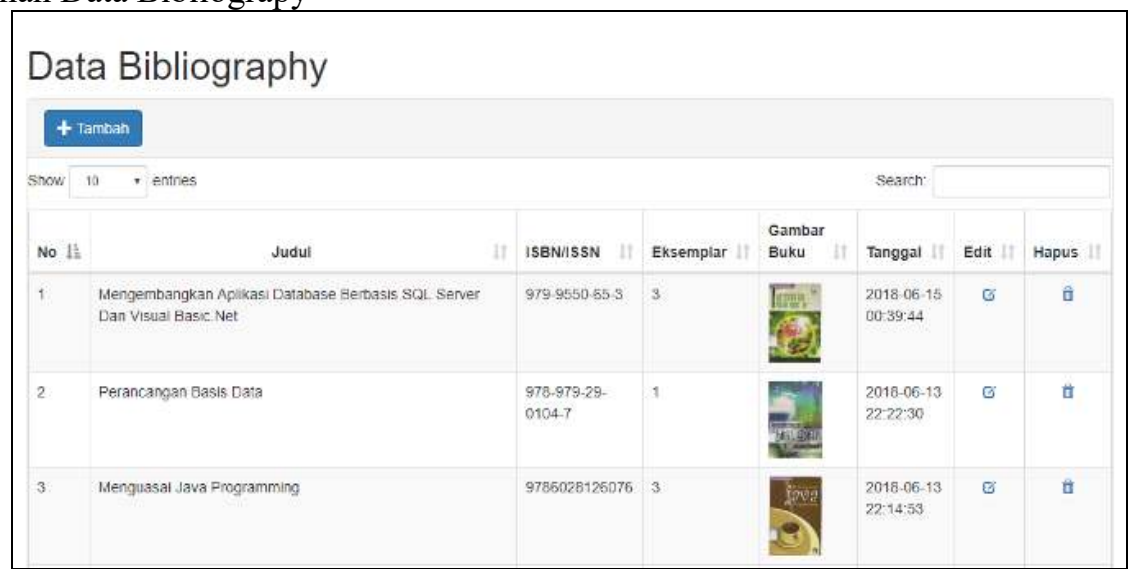

Gambar 8 Halaman Data Bibliograpy

Pilih menu Bibliograpy dan klik bibliograpy, maka akan tampil seperti pada gambar 8. Admin dapat melakukan tambah data, edit dan hapus bibliograpy dengan cara mengklik tombol tambah, edit data dan hapus.

9. Halaman Data Eksemplar

\begin{tabular}{|c|c|c|c|c|c|c|c|c|c|}
\hline \multicolumn{10}{|c|}{ + Tambah } \\
\hline Show 10 & - entries & & & & & & Search: & & \\
\hline No $\quad \downarrow \underline{E}$ & Kode Eksemplar & ti & No Panggil & $\downarrow$ & Status & 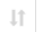 & Edit $\|$ & Hapus & lt \\
\hline 1 & 899jtaub5622 & & 005.7585 Men m c3 & & TS & & $\mathbb{G}$ & 吉 & \\
\hline 2 & 899jtaub5575 & & 005.7585 Men m c2 & & TS & & $G$ & 告 & \\
\hline 3 & 899jtaub5696 & & 005.7585 Men m c1 & & TS & & $E$ & 吉 & \\
\hline 4 & 899jtaub5573 & & 005.7 Sum $p c 1$ & & TS & & 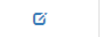 & 量 & \\
\hline 5 & 899jtaub7302 & & 005.133 Men m c3 & & TS & & E & 苗 & \\
\hline
\end{tabular}

Gambar 8 Halaman Data Eksemplar

10.Halaman Aktivasi Data Anggota 


\begin{tabular}{|l|}
\hline Aktivasi Data Anggota \\
ID Anggota \\
\hline 2147100699 \\
Nama Anggota \\
Ayub Kukuh Prasetyo \\
Alamat \\
\hline Singkoyo \\
E-mai \\
\hline ayub_kukuh@yahoo. co. id \\
No. Hp \\
\hline 081238486669 \\
Tanggal Daftar \\
2018-06-10 \\
Tipe Anggota \\
\hline Mahasiswa \\
Status Anggota \\
\hline Aktif \\
\hline \pm Simpan \\
\hline
\end{tabular}

Gambar 9 Halaman Aktivasi Data Anggota

Pada gambar 9 halaman aktivasi data anggota, admin dapat melakukan aktivasi anggota, dengan cara merubah status anggota menjadi aktif melalui opsi status anggota. Setelah itu klik tombol simpan untuk menyimpan perubahan status anggota dan sistem akan otamatis mengirimkan email kepada anggota yang statusnya telah aktif. Anggota yang telah dinyatakan aktif, akan dapat melakukan login kedalam aplikasi perpustakaan. Jika status anggota tidak aktif, maka anggota tidak dapat melakukan login kedalam aplikasi perpustakaan.

11.Halaman Data Tipe Anggota

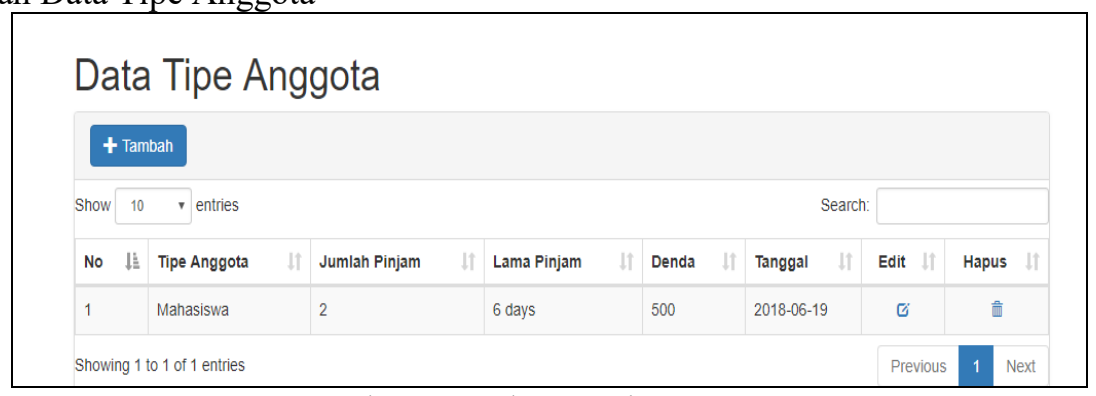

Gambar 10 Halaman Tipe Anggota

12.Halaman Daftar Peminjam Buku

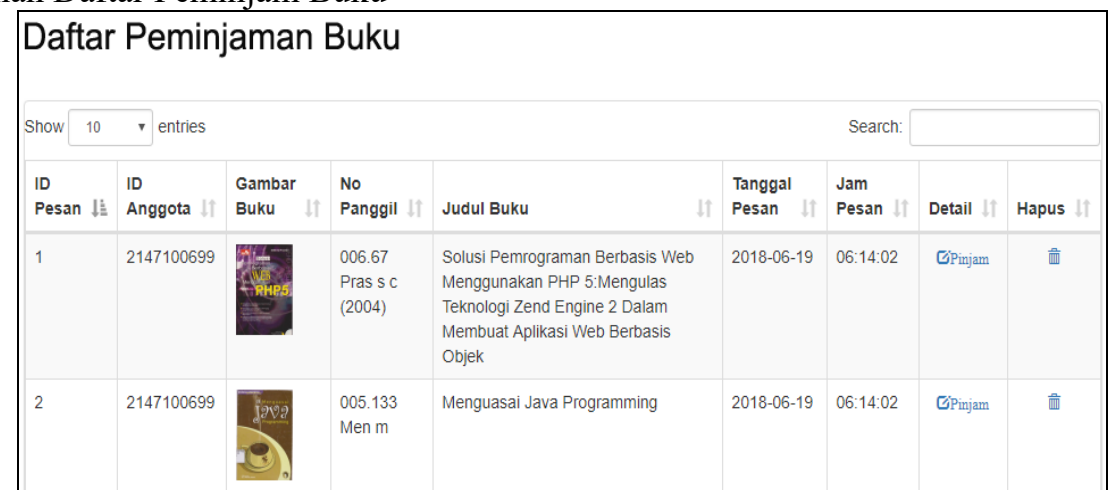

Gambar 11 Halaman Daftar Peminjam Buku 
13.Halaman Pengembalian Buku

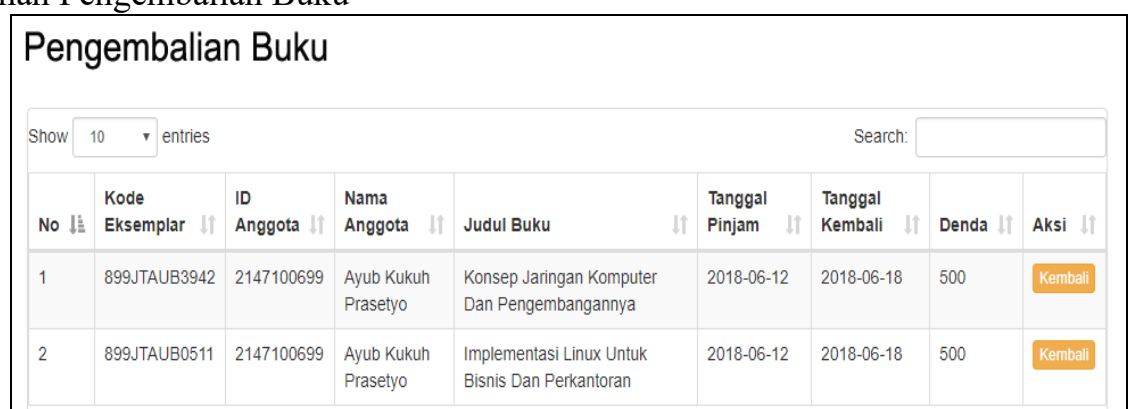

Gambar 12 Halaman Pengembalian Buku

14.Halaman Riwayat Peminjam Buku

\begin{tabular}{|c|c|c|c|c|c|c|c|c|}
\hline \multicolumn{9}{|c|}{ Daftar Riwayat Peminjaman } \\
\hline \multicolumn{9}{|c|}{ Show $10 \quad$ entries } \\
\hline No $\downarrow \mathbb{E}$ & $\begin{array}{l}\text { Kode } \\
\text { Eksemplar } t f\end{array}$ & $\begin{array}{l}\text { ID } \\
\text { Anggota }\end{array}$ & $\begin{array}{l}\text { Nama } \\
\text { Anggota }\end{array}$ & Judul Buku & $\begin{array}{l}\text { Tanggal } \\
\text { Pinjam } \downarrow \uparrow\end{array}$ & $\begin{array}{l}\text { Tanggal } \\
\text { kembali }\end{array}$ & Denda $\downarrow t$ & Status $\|$ \\
\hline 1 & 899jtaub7302 & 2147100699 & ayub & Menguasai Java Programming & $2018-06-05$ & 2018-06-19 & 5.000 & Kembali \\
\hline 2 & 899JTAUB4068 & 2147100699 & ayub & Menguasai Java Programming & 2018-06-19 & 2018-06-19 & 0 & Kembali \\
\hline 3 & 899jtaub5696 & 2147100699 & ayub & $\begin{array}{l}\text { Mengembangkan Aplikasi } \\
\text { Database Berbasis SQL Server } \\
\text { Dan Visual Basic.Net }\end{array}$ & 2018-06-19 & $2018-06-19$ & 0 & Kembali \\
\hline 4 & 899JTAUB4068 & 2147100699 & ayub & Menguasai Java Programming & 2018-06-19 & 2018-06-19 & 0 & Kembali \\
\hline 5 & 899JTAUB3942 & 2147100699 & ayub & $\begin{array}{l}\text { Konsep Jaringan Komputer Dan } \\
\text { Pengembangannya }\end{array}$ & 2018-06-12 & 2018-06-19 & 0 & Kembali \\
\hline 6 & 899JTAUB0511 & 2147100699 & ayub & $\begin{array}{l}\text { Implementasi Linux Untuk Bisnis } \\
\text { Dan Perkantoran }\end{array}$ & $2018-06-12$ & 2018-06-19 & 0 & Kembali \\
\hline
\end{tabular}

Gambar 13 Halaman Riwayat Peminjam Buku

15.Halaman Usulan Penambahan Data Buku

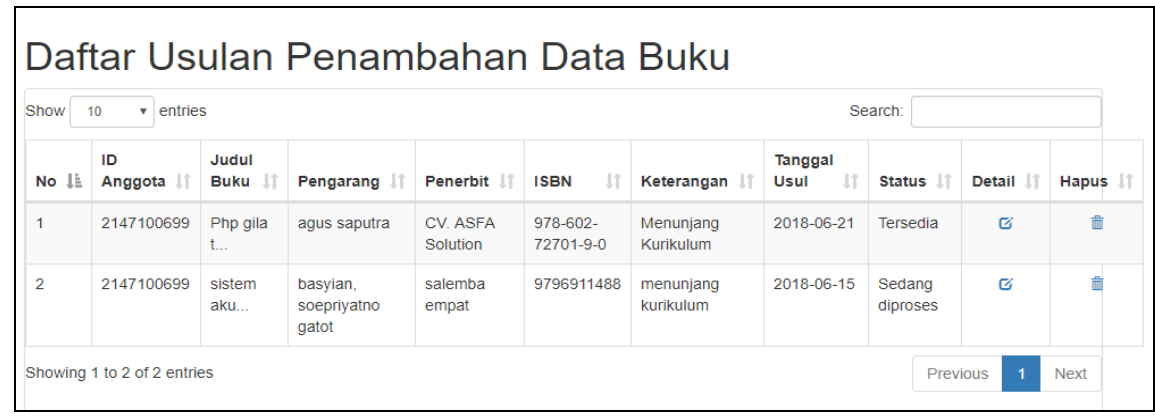

Gambar 13 Halaman Riwayat Peminjam Buku

16.Tampilan Laporan

GO INFOTECH: JURNAL ILMIAH STMIK AUB Vol. 25, No. 2, Desember 2019: 97-111 


\begin{tabular}{|c|c|c|c|c|}
\hline (9) & \multicolumn{3}{|c|}{$\begin{array}{c}\text { STMIK AUB SURAKARTA } \\
\text { Kantor Pusat : JL MW.maramis } \\
\text { Telp. (0271)857070, Fax (0271) } 857070\end{array}$} & Tanggal : 2018-07-05 \\
\hline \multicolumn{5}{|c|}{ LAPORAN DATA BUKU } \\
\hline No & Judul Buku & Pengarang & Penerbit & Stok \\
\hline 1 & Visual Basic 2012 Programming & Wahana Komputer & Andi : Semarang & 3 \\
\hline 2 & Android Programming With Eclipse & Wahana Komputer & Andi : Yogyakarta & 3 \\
\hline 3 & $\begin{array}{l}\text { Konsep Jaringan Komputer Dan } \\
\text { Pengembangannya }\end{array}$ & Wahana Komputer & $\begin{array}{l}\text { Salemba Infotek: } \\
\text { Jakarta }\end{array}$ & 3 \\
\hline 4 & $\begin{array}{l}\text { Implementasi Linux Untuk Bisnis Dan } \\
\text { Perkantoran }\end{array}$ & Wahana Komputer & $\begin{array}{l}\text { Salemba Infotek: } \\
\text { Jakarta }\end{array}$ & 8 \\
\hline 5 & $\begin{array}{l}\text { Membuat Sendiri Aplikasi Web Mobile } \\
\text { Menggunakan JQuery Mobile }\end{array}$ & Wahana Komputer & \begin{tabular}{|l} 
Andi : Yogyakarta \\
\end{tabular} & 3 \\
\hline 6 & $\begin{array}{l}\text { Mudah Membuat Game Android } \\
\text { Berbasis Adobe AIR }\end{array}$ & Wahana Komputer & Andi : Yogyakarta & 3 \\
\hline 7 & $\begin{array}{l}\text { Pengembangan Web Di Linux Dengan } \\
\text { Apache, MySQL, Dan PHP (LAMP) }\end{array}$ & Wahana Komputer & $\begin{array}{l}\text { Salemba Infotek: } \\
\text { Jakarta }\end{array}$ & 3 \\
\hline 8 & Menguasai Java Programming & Wahana Komputer & $\begin{array}{l}\text { Salemba Infotek: } \\
\text { Jakarta }\end{array}$ & 3 \\
\hline
\end{tabular}

Gambar 14 Laporan Data Buku

\begin{tabular}{|c|c|c|c|c|c|}
\hline & & & $\begin{array}{l}\text { STMIK AUB SURAKARTA } \\
\text { Kantor Pusat : JL MW.maramis } \\
\text { Telp. (0271)857070, Fax (0271) 857070 }\end{array}$ & \multicolumn{2}{|c|}{ Tanggal : 2018-07-12 } \\
\hline NO & ID ANGGOTA & KD EKSEMPLAR & JUDUL BUKU & TGL PINJAM & STATUS \\
\hline 1 & 2147100696 & 899jtaub5566 & UML Distiled: Panduan Singkat Tentang Bahasa Permodelan Objek Standar. Edisi Ket & $2018-07-12$ & Dipinjam \\
\hline 2 & 2147100687 & 899JTAUB5717 & Menguasai Java Programming & $2018-07-12$ & Dipinjam \\
\hline 3 & 2147100687 & 899JTAUB3609 & Excel With VBA And Macro: Membuat Aplikasi Dengan Excel Kenapa Tidak? & $2018-07-12$ & Dipinjam \\
\hline 4 & 2147100703 & 899JTAUB3676 & Mudah Membuat Game Android Berbasis Adobe AIR & $2018-07-12$ & Dipinjam \\
\hline 5 & 2147100703 & 899jtaub3649 & Sistem Keamanan Komputer & $2018-07-12$ & Dipinjam \\
\hline 6 & 2147100688 & 899jtaub5696 & Mengembangkan Aplikasi Database Berbasis SQL Server Dan Visual Basic.Net & $2018-07-12$ & Dipinjam \\
\hline 7 & 2147100688 & 899jtaub2733 & Solusi Pemrograman Berbasis Web Menggunakan PHP 5:Mengulas Teknologi Zend Engine & 2018-07-12 & Dipinjam \\
\hline
\end{tabular}

Gambar 15 Laporan Peminjaman Buku

\begin{tabular}{|c|c|c|c|c|c|c|}
\hline \multicolumn{7}{|c|}{ LAPORAN USULAN PENAMBAHAN DATA BUKU } \\
\hline NO & ID ANGGOTA & JUDUL BUKU & PENGARANG & THN TERBIT & ISBN & STATUS \\
\hline 1 & 2147100699 & sistem akutansi sekyor publik : konsep untuk pemefintah daerah & basyian, soepriyatno gatot & 2003 & 9796911488 & Sedang diproses \\
\hline 2 & 2147100699 & Php gila trik dahsyat menjadi master php & agus saputra & 2016 & 978-602-72701-9-0 & Sedang diproses \\
\hline 3 & 2147100703 & proyek Aplikadi ANDROID dengan Visual Studio Xamarin Dan Coo & Ipung Purwono & 2018 & $978602-6231-15-4$ & Sedang diproses \\
\hline 4 & 2147100703 & Trik Kolaborasi Android dengan php Dan mysql & Akhmad Dharma Kasman & 2015 & $978-602-71905-7-3)$ & Sedang diproses \\
\hline 5 & 2147100697 & Bikin Aplikasi ANDROID dengan angular mobile Dan mongoDB & Agung Julisman & 2015 & $978-602-71905-0-4$ & Sedang diproses \\
\hline 6 & 2147100697 & program absensi siswa realtime dengan php Dan sms gateway & Aminudin & 2014 & 978-602-14406-9-9 & Sedang diproses \\
\hline
\end{tabular}

Gambar 16 Laporan Penambahan Data Buku

17.Kartu Anggota

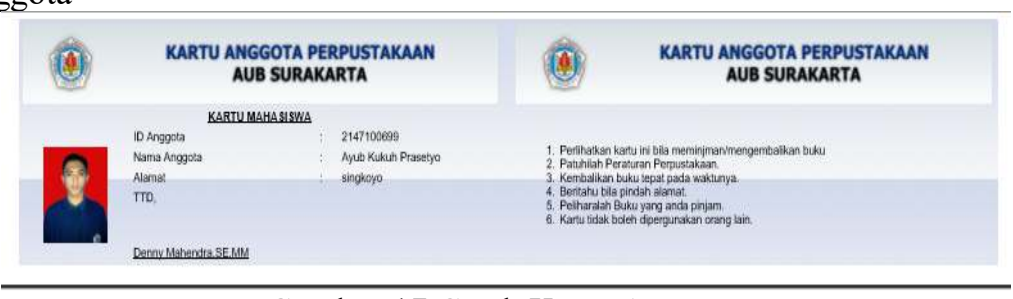

Gambar 17 Cetak Kartu Anggota

3.2 Antar muka halaman anggota berbasis android

1. Tampilan Daftar Anggota 


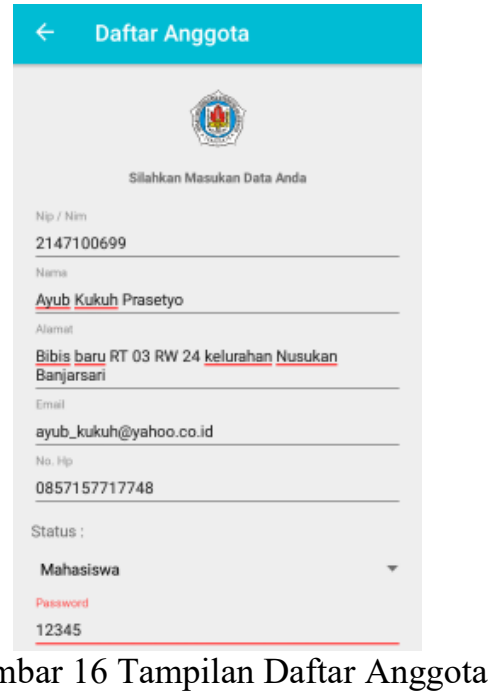

2. Tampilan Menu Aplikasi

$$
\text { Gambar } 16 \text { Tampilan Daftar Anggota }
$$

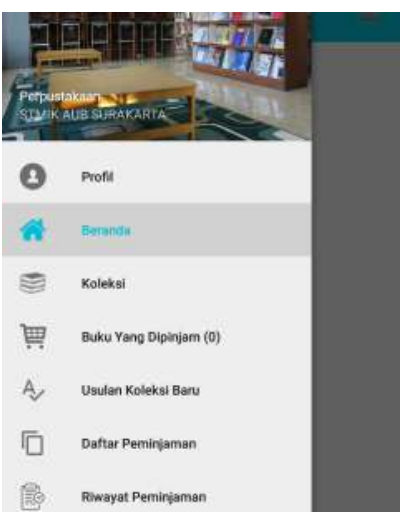

3. Tampilan Koleksi Buku

Gambar 16 Tampilan Menu Aplikasi

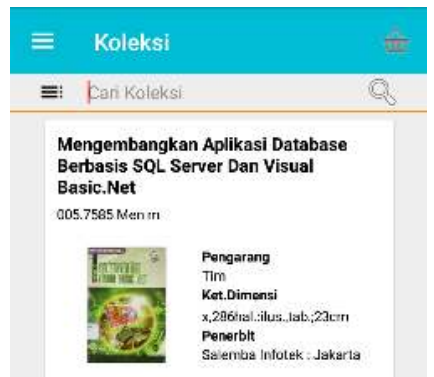

Gambar 17 Tampilan Koleksi Buku

4. Tampilan Detail Koleksi Buku 


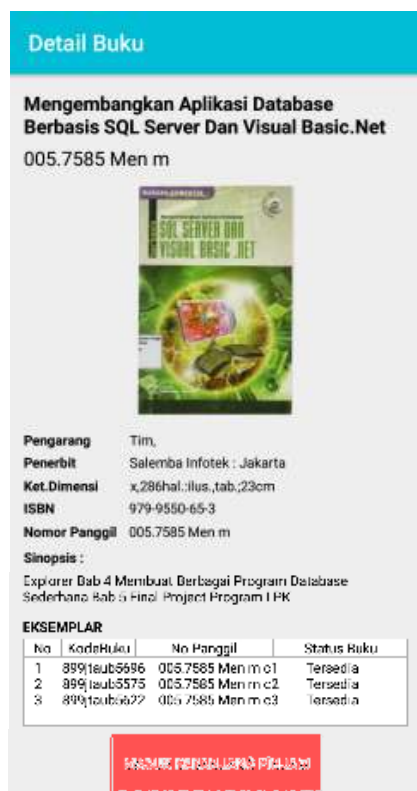

5. Tampilan Keranjang Buku

Gambar 16 Tampilan Detail Koleksi Buku

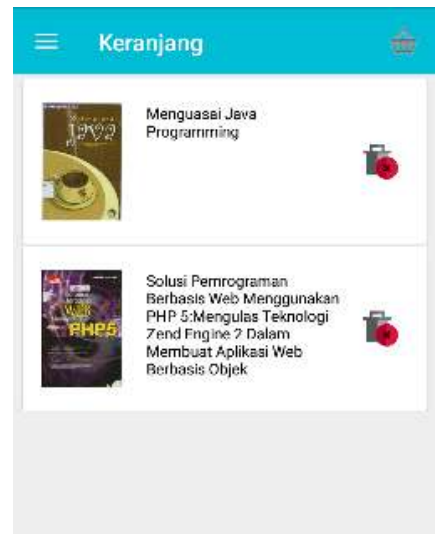

Gambar 16 Tampilan Keranjang Buku

6. Tampilan Buku yang Dipinjam

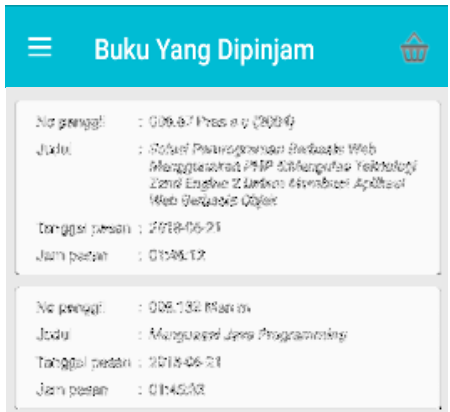

7. Tampilan Daftar Peminjam

Gambar 17 Tampilan Buku yang Dipinjam 


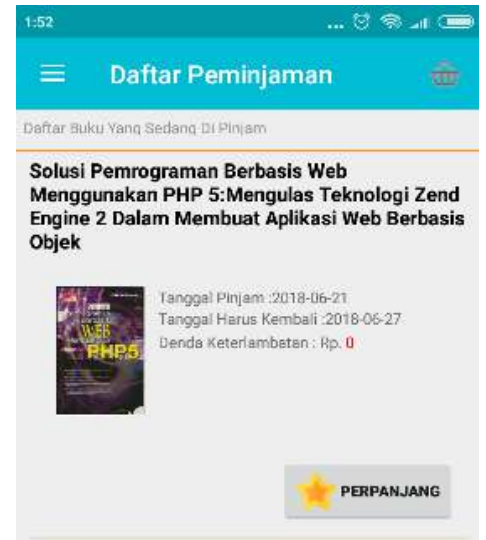

Gambar 18 Tampilan Daftar Peminjam

Gambar 18 informasi peminjaman yang terdiri dari judul buku, gambar buku, tanggal pinjam, tanggal kembali, dan denda keterlambatan. Anggota dapat melakukan perpanjangan massa pinjam buku, selama belum melewati batas tanggal pengembalian. Dengan cara mengklik tombol perpanjang. Maka massa peminjaman buku otomotis diperpanjang dan akan tampil message "massa pinjam buku sukses diperpanjang".

\section{KESIMPULAN}

Pada perancangan sistem perpustakaan STMIK AUB Surakarta berbasis android menggunakan metode pengumpulan data yaitu metode wawancara, observasi dan studi pustaka. Yang menggunakan sumber data primer dan data sekunder. Untuk metode perancangan sistem menggunakan Flowchart, UML (Unified Modeling Language) yang tediri dari Usecase Diagram, Activity Diagram, Sequence Diagram, Class Diagram, dan Entity Relationship Diagram. Sedangkan untuk metode pengembangan sistem menggunakan metode Waterfall. Hasil dari perancangan sistem yaitu Sistem Pepustakaan STMIK AUB berbasis android. Pengembangan sistem menggunakan bahasa pemrograman Java, tool yang digunakan yaitu Android Studio Versi 3.0.1, pada website menggunakan bahasa pemrograman PHP, dan SQL sebagai database. Pada sisi server, sistem ini dapat melakukan pengolahan data buku, aktivasi data anggota, sirkulasi peminjaman pengembalian buku dan pembuatan laporan. Pada sisi client sistem dapat melakukan peminjaman buku, perpanjangan masa pinjman buku dan melihat riwayat peminjaman buku. Adanya Aplikasi Perpustakaan STMIK AUB Surakarta Berbasis Android, memberikan media baru bagi anggota dalam menyediakan layanan informasi koleksi buku dan peminjaman buku secara online. Selain itu juga dilengkapi dengan daftar peminjaman koleksi buku, riwayat peminjaman koleksi buku, usulan penambahan koleksi buku, berita terbaru seputar perpustakaan dan adanya notification saat buku telah dikembalikan. Hasil dari penelitian ini adalah Aplikasi Perpustakaan STMIK AUB Surakarta Berbasis Android, dengan adanya aplikasi ini diharapkan dapat meningkatkan kinerja layanan informasi, transaksi peminjaman di Perpustakaan STMIK AUB.

\section{SARAN}

Aplikasi Perpustakaan SMIK AUB Surakarta Berbasis Android ini masih dapat dikembangkan lebih lanjut, yaitu: Aplikasi yang dibuat sudah dapat melakukan peminjaman buku ketika anggota tidak berada diperpustakaan. Namun dapat dikembangkan lagi dengan fungsionalitas barcode untuk peminjaman buku secara langsung. Yang nantinya anggota dapat melakukan peminjaman buku dengan menscan barcode kode buku. Pada aplikasi jenis koleksi berupa buku teks, namun dapat dikembangakan lagi dengan menambahkan jenis koleksi seperti

GO INFOTECH: JURNAL ILMIAH STMIK AUB Vol. 25, No. 2, Desember 2019: 97-111 
jurnal dan laporan penelitian yang memungkinkan anggota dapat mengetahui refrensi buku yang ada diperpustakaan selain buku koleksi yang ada. Pada aplikasi sudah terdapat fungsionalitas notification ketika anggota mengembalikan buku diperpustakaan, namun dapat dikembangkan lagi dengan menambahkan fungsionalitas notification keterlambatan pengembalian buku ketika anggota terlambat mengembalikan buku.

\section{DAFTAR PUSTAKA}

[1] Andri Kristanto, 2003. Perancangan Sistem Informasi dan Aplikasinya, Penerbit: Gava Media, Jakarta.

[2] Bambang Haryanto, 2011. Esensi-esensi Bahasa Pemrograman Java, Yogyakarta: Penerbit Andi.

[3] Bausa, Yusuf. 2017. Analisis Dan Perancangan Aplikasi Peminjaman Pada Perpustakaan Universitas Amikom Yogyakarta Berbasis Android Skripsi: Universitas Amikom Yogyakarta.

[4] Coupey, Eloise. (2001). Marketing and The Internet. Prentice Hall, New Jersey.

[5] DeCoster. 2012. Pengertian Java Development Kit. from http://library.binus.ac.id, diakses pada tanggal 21 November 2017.

[6] Erudeye.2015.Pengertian html php dan mysql. http://abstrak.ta.uns.ac.id/wisuda/upload/M2114046_bab1 diakses pada tanggal 8 Maret 2018.

[7] Henkie, Ongowarsito (2008) Teknologi Informasi Untuk Perpustakaan: Digital Library Sebagai Solusi Keterbatasan Informasi. Jurnal Piranti Warta, ISSN 1411 - 2221

[8] Jogiyanto. 2005. Analisis dan Desain Sistem Informasi. Yogyakarta: Penerbit Andi.

[9] Json. 2018. Pengenalan Json. https://www.json.org/json-id.html diakses pada 5 Maret 2018.

[10] Kusumatuti, Febriani. 2012. Aplikasi Perpustakaan Online Berbasis Android dan PHP Menggunkan Protokol JSON Jurnal: Fakultas Teknologi Industri Universitas Gunadarma.

[11] Pressman, Roger, S. (2001), Software Engineering: A Practitioner's Approach, Fifth Ed. New York, McGraw-Hill Book Company.

[12] Putra, Yudha Wastu Vira Anatya. 2012. Rancang Bangun Sistem Informasi Katalog Berbasis Android di Perpustakaan Umum Daerah Surabaya. Skripsi: Universitas Pembangunan Nasional Veteran Jawa Timur.

[13] Safaat, Nazrudi. 2012. Android Pemrograman Aplikasi Mobile Smartphone dan Tablet PC Berbasis Android.Bandung:Informastika.

[14] Sandi, Mulyana. 2014. Bikin Website Dengan Aplikasi-aplikasi Gratis Cepat, Mudah \& Murah. Yogyakarta: MediaKom.

[15] Shalahuddin, M. 2015. Rekayasa Perangkat Lunak Terstruktur Dan Berorientasi Objek. Bandung: INFORMATIKA.

[16] Sugiyono, 2013, Metodelogi Penelitian Kuantitatif, Kualitatif Dan R\&D. (Bandung: ALFABETA).

[17] Sulistyo, Basuki, 2009. Pengantar Ilmu Perpustakaan, Jakarta: Universitas Terbuka.

[18] Suyanto. 2004. Analisis dan Desain Aplikasi Multimedia. Yogyakarta: Andi.

[19] Usman, Husnaini dan Akbar, Purnomo Setyadi. 2000. Metodologi Penelitian Sosial. Jakarta: PT. Bumi Aksara.

[20] Wikipedia. 2017. Aplikasi. https://id.wikipedia.org/wiki/Aplikasi diakses pada 26 Oktober 2017 